\title{
THE EFFECT OF WELDING CURRENT ON AISI 1045 STRENGTH AND CORROSION RATE
}

\author{
Iftika Philo Wardani ${ }^{1}$, Vuri Ayu Setyowati ${ }^{1}$, Suheni ${ }^{1}$, Ilham Prajala Samudra ${ }^{1}$ \\ ${ }^{1}$ Program Studi Teknik Mesin, Institut Teknologi Adhi Tama Surabaya, Indonesia \\ Email: iftika.wardani@itats.ac.id
}

\begin{abstract}
Abstrak
Shielded Metal Arc Welding (SMAW) merupakan jenis pengelasan yang banyak digunakan dalam proses penyambungan baja AISI 1045 karena alatnya yang sederhana, murah, dan portabel. Penelitian ini ditujukan untuk mengetahui pengaruh variasi arus pengelasan terhadap kekuatan material dan laju korosi material AISI 1045. Variasi arus yang akan digunakan pada penelitian ini adalah 100, 110, dan 120 Ampere. Penelitian dilakukan dengan melakukan pengujian tarik pada daerah lasan serta pencelupan sekitar daerah lasan pada larutan $\mathrm{NaCl}$ konsentrasi $0.4 \%$. Dari penelitian yang dilakukan diketahui bahwa semakin naik arus pengelasan maka nilai kekuatan luluh, tarik, dan patah material akan semakin naik pula. Demikian juga pada nilai elongasi material yang akan meningkat dengan naiknya arus pengelasan. Selain berpengaruh pada kekuatan dan elongasi material, arus pengelasan juga berpengaruh pada laju korosi, dimana laju korosi material semakin naik seiring dengan naiknya arus pengelasan yang diberikan.
\end{abstract}

Kata Kunci: AISI 1045, Kekuatan material, Laju korosi, Pengelasan SMAW

\begin{abstract}
Shielded Metal Arc Welding (SMAW) was widely used in industry for joining AISI 1045 steel because this method was simple, in-expensive, and the device is portable. This researched aimed to analyze the effect of variations in welding current towards material strength and corrosion rate of AISI 1045. Welding current that been used as variations in this study are 100, 110, and 120 Ampere. This research was conducted using tensile test on the weld area and immersion around the weld area in $\mathrm{NaCl}$ solution with $0.4 \%$ concentration. From the research that conducted, it is known that increasing in welding current made the yield strength, tensile strength, and fracture strength of material also increased. This phenomenon also happened for elongation of material in weld area. With increasing the welding current then the elongation of material also increasing. Another aspect that researched in this paper is the effect of welding current toward corrosion rate of material. From the result, it was known that increasing welding current made corrosion rate of material became faster.
\end{abstract}

Keywords: AISI 1045, Corrosion rate, Material Strength, SMAW

\section{Introduction}

AISI 1045 was widely used in industry for its behavior. This material was easily to forging, cold drawing, machining, and also has good wear resistance. This material also easily to be treated with heat treatment (including flame hardening). Usually, this material was used as bolts, crankshaft, gears, and guide rods[1], [2]. AISI 1045 was classified as medium carbon steel with carbon content between $0.43-0.50 \% \mathrm{C}$. This steel has yield strength $305 \mathrm{MPa}$, tensile strength $580 \mathrm{MPa}$, and elongation $16 \%[1]$.

It was commonly known that during fabrication process, welding was crucial process for joining two or more materials. The commonly used welding process for AISI 1045 is Shielded Metal Arc Welding (SMAW), because this method had simple device, in-expensive, and also portable. Another reason for choosing this method is because this welding method can be used to increasing wear resistance using hard facing or wear facing[3]. In every welding process, there are several welding parameters that will affect the result of welding, they are welding current, welding voltage, polarity, and welding speed[3]. In this paper, will only focused on welding current parameter. 
The effect of welding current of SMAW welding on low carbon steel had been researched by M. Khafifudin. The research that conducted by M. Kahafifudin was done using welding current variation of $65,75,85 \mathrm{~A}$. From the researched that been done, it was known that the tensile strength will decreasing along with increasing welding current. Another finding of this researched is welding process will make the tensile strength of the welded area on low carbon steel is lower than its base material[4].

Rohit Jha and A.K.Jha had also studied about the effect of welding current of SMAW method towards tensile strength of low carbon steel. From this study, it was known that the maximum tensile strength was achieved when welding current was set on 120 A. From their study, it also known that elongation of welded steel was increasing from $100 \mathrm{~A}$ until $120 \mathrm{~A}$, and then it tend to be stagnan after $120 \mathrm{~A}[5]$.

AISI 1045 tend to be corroded if not protected well, be it in the base metal or weld metal. So, in this paper will also studied the effect of the welding current toward corrosion rate of AISI 1045. To calculate the corrosion rate we can use two method, there are weight loss method and electrochemical method [6]. In this paper, the calculation of corrosion rate will be done by weight loss method only. In the weight loss method, the corrosion rate was calculate using the weight changing after material been put in the corrosion environment for some time. This method can be described using equation 1[6].

corrosion rate $(m p y)=\frac{K \times W}{A \times T \times D}$

Where $\mathrm{K}$ is a constant, in this case, the constant for mpy was $3.45 \times 10^{6}, \mathrm{~W}$ (gram) is mass that lost from corrosion process, A $\left(\mathrm{cm}^{2}\right)$, is cross-area of the specimen, $\mathrm{T}$ (hour), is time of exposure in corrosion environment, and $\mathrm{D}\left(\mathrm{g} / \mathrm{cm}^{3}\right)$, is the density of the AISI 1045 . The correlation of the corrosion rate and corrosion resistance can be seen in the Table 1 .

Table 1. Correlation between corrosion rate and corrosion resistance [7]

\begin{tabular}{|l|c|c|c|c|c|}
\hline \multirow{2}{*}{$\begin{array}{c}\text { Relative } \\
\begin{array}{c}\text { Corrosion } \\
\text { Resistance }\end{array}\end{array}$} & \multicolumn{5}{|c|}{ Approximate Metric Equivalent } \\
\cline { 2 - 7 } & mpy & mm/year & $\mu m / y r$ & am/yr & pm/sec \\
\hline Outstanding & $<1$ & $<0.02$ & $<25$ & $<2$ & $<1$ \\
\hline Excellent & $1-5$ & $0.02-$ & $25-100$ & $2-10$ & $1-5$ \\
\hline Good & $5-20$ & $0.1-0.5$ & $\begin{array}{c}100- \\
500\end{array}$ & $10-50$ & $5-20$ \\
\hline Fair & $20-50$ & $0.5-1$ & $\begin{array}{c}500- \\
1000\end{array}$ & $\begin{array}{c}50- \\
100\end{array}$ & $20-50$ \\
\hline Poor & $50-$ & $1-5$ & $\begin{array}{c}1000- \\
5000\end{array}$ & $\begin{array}{c}150- \\
500\end{array}$ & $50-200$ \\
\hline Unacceptable & $200+$ & $5+$ & $5000+$ & $500+$ & $200+$ \\
\hline
\end{tabular}

From the Table 1, can be seen that the bigger value of the mpy then the poorer its corrosion resistance. With mpy value reaches 50 mpy than the material had poor corrosion resistance, so it will bad choices if we stick to this material.

Priyantoro, et al, conducted a study on the effect of scratch area on plate A36 toward corrosion rate. From the research that conducted, it was known that the larger the scratch area that exposed to the corrosion environment then the corrosion rate rate will be larger too. And on the A36 plate that welded by SMAW welding, it was known that the HAZ area which has an scratch area of $10 \%$ will have corrosion rate of 0.3788 mpy. In addition, the authors also conclude that the SMAW welding method produces the highest corrosion rates comparing to FCAW and GMAW welding[8].

Ojahan R, et al., also conducted a study on the corrosion rate of A36 steel using SMAW welding in seawater media, $10 \% \mathrm{NaCl}, 20 \% \mathrm{NaCl}$ and $30 \% \mathrm{NaCl}$ solution. From their research, it is known that the highest corrosion rate value is obtained from the SMAW-welded on the $20 \% \mathrm{NaCl}$ solution, with a corrosion rate of 0.002066 mpy. In addition, from the research that been conducted, it was also known that the corrosion that occurs in SMAW welding was evenly distributed[9]. 


\section{Methods}

In this paper, the raw material that been used was plate with thickness of $18 \mathrm{~mm}$. The plate then machining to formed V- shaped grooved, and then weld the plate with SMAW using LB-52-18 electrodes with a diameter of $3.2 \mathrm{~mm}$ and a current variation of 100,110 and 120 Ampere. After that, the welded plate then machined again into Tensile test specimen based on ASME Sec. IX as described in Figure 1. The specimen then tested with universal tensile testing machine.

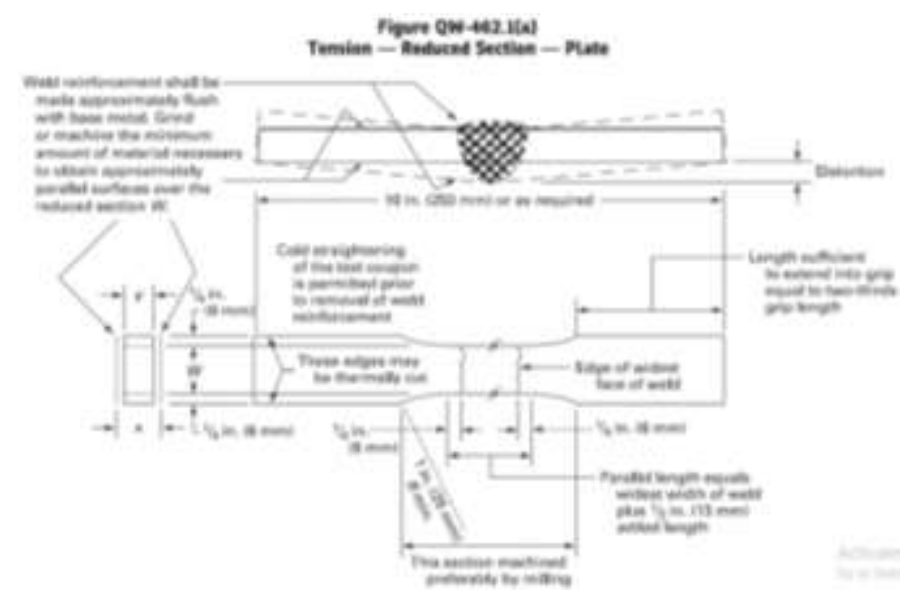

Figure 1. Tensile Test specimen based on ASME Sec. IX [10]

As for corrosion rate test, the welded plate was machining as square shaped with dimension 50 x $50 \mathrm{~mm}$. Then, the initial mass of specimen was measured. After that, process was continued by soaking the test object for 120 hours in to $\mathrm{NaCl}$ solution with concentration of $0.4 \%$. After that, the specimen was carried out to be weighed. Then calculate the corrosion rate using equation 1.

\section{Result and Discussion}

The effect of welding current on the mechanical properties of AISI 1045 steel

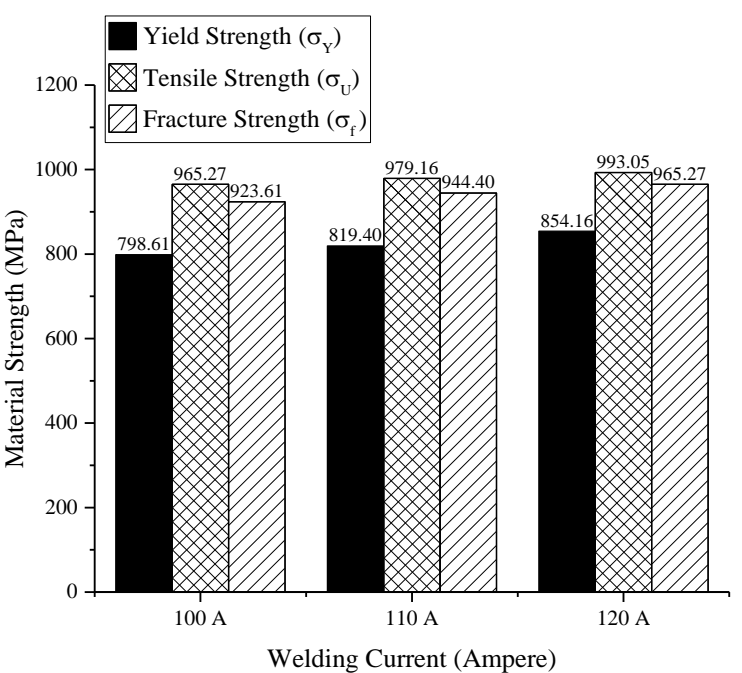

Based on

Figure 2, it was known that welding process made yield strength and tensile strength of AISI 1045 higher than its base material. And the increasing is quite high, considering that according to standard, the yield strength and tensile strength of AISI 1045 are around $305 \mathrm{MPa}$ and $508 \mathrm{MPa}$. After this material been welded, its yield strength and tensile strength reached $923.61 \mathrm{MPa}$ at 100 Ampere, so the increasing of its strength reaches more than $200 \%$. From Figure 2, it also can be seen that with 
increasing the welding current, then the yield strength, tensile strength, and fracture strength of the material also increasing.

From the Figure 3, it is known that with a current of 100 Ampere, the material elongation is $4.6 \%$, at current 110 Ampere the material elongation is 5.2\%, and at a current of $120 \mathrm{~A}$ the material elongation continued to rise until reaching $5.6 \%$. It can be concluded that increasing the welding current made the elongation of the material also getting higher.

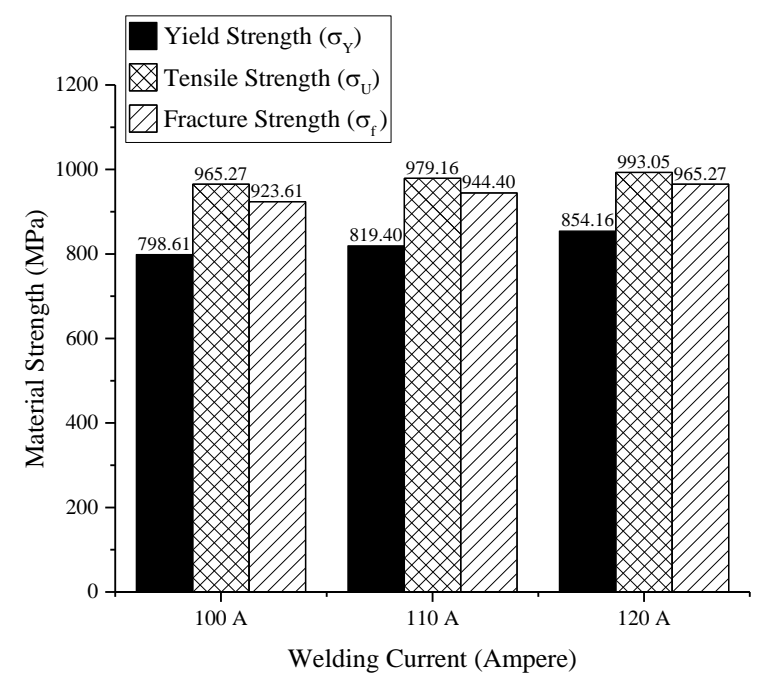

Figure 2. Yield Strength, Tensile Strength, and fracture strength of AISI 1045 toward welding current

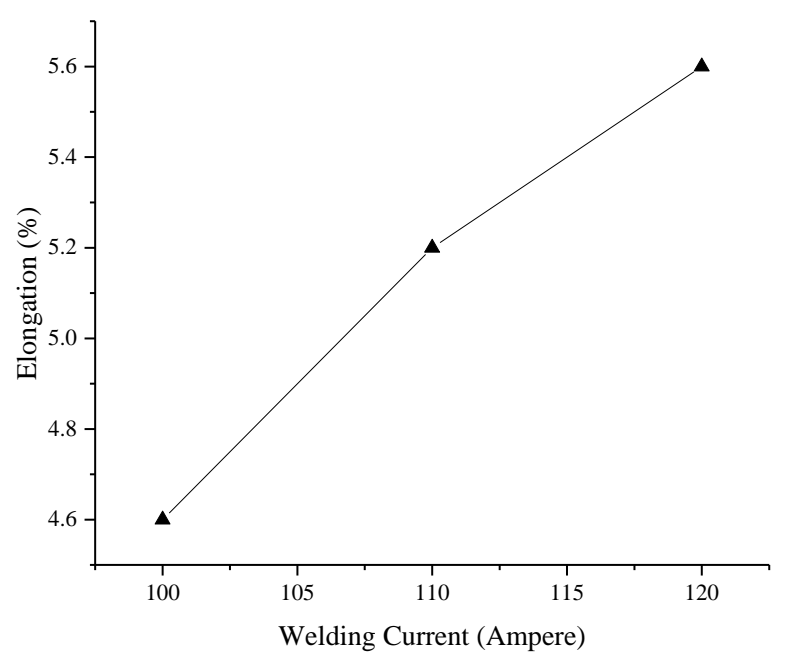

Figure 3. Elongation of AISI 1045 toward welding current

\section{The effect of welding current toward corrosion rate of AISI 1045}

From the weight loss tests that been carried out, the results are shown in Table 2

Table 2. The Decreasing mass of specimen

\begin{tabular}{cccc}
\hline $\begin{array}{c}\text { Welding current } \\
(\text { Amp })\end{array}$ & $\begin{array}{c}\text { Initial mass } \\
(\mathrm{g})\end{array}$ & $\begin{array}{c}\text { Final mass } \\
(\mathrm{g})\end{array}$ & $\begin{array}{c}\text { Decreasing of mass } \\
(\%)\end{array}$ \\
\hline 100 & 411.03 & 410.56 & 0.114 \\
\hline 110 & 437.02 & 436.49 & 0.121 \\
\hline 120 & 449.54 & 448.96 & 0.129 \\
\hline
\end{tabular}

Using data from Table 2 and equation 1, then the corrosion rate that experienced by specimen can be shown in Figure 4 and Figure 5 


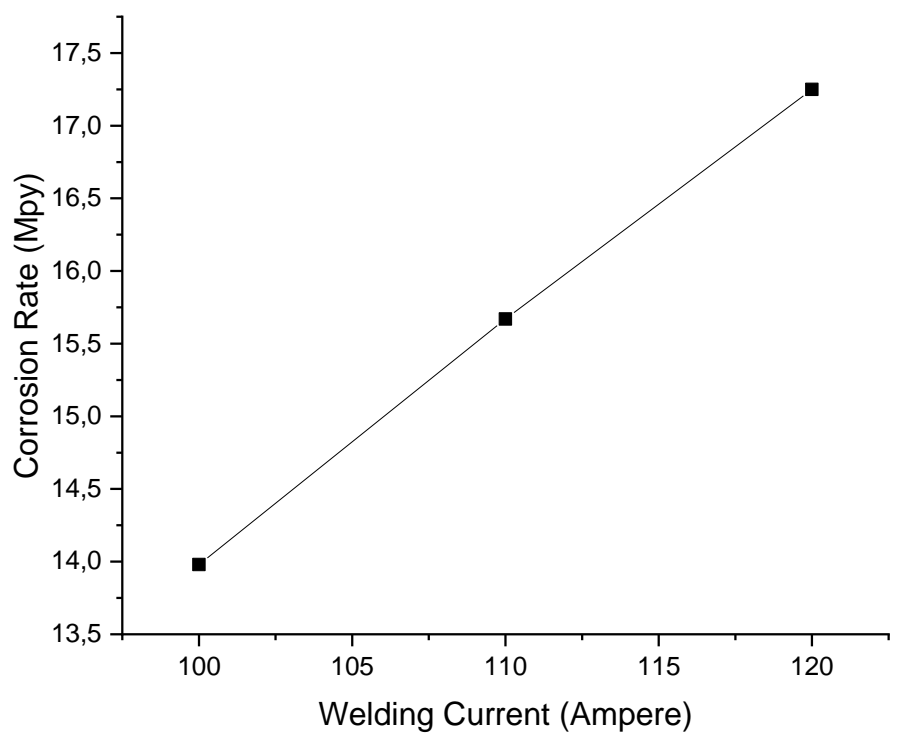

Figure 4. The correlation between Corrosion rate and welding current

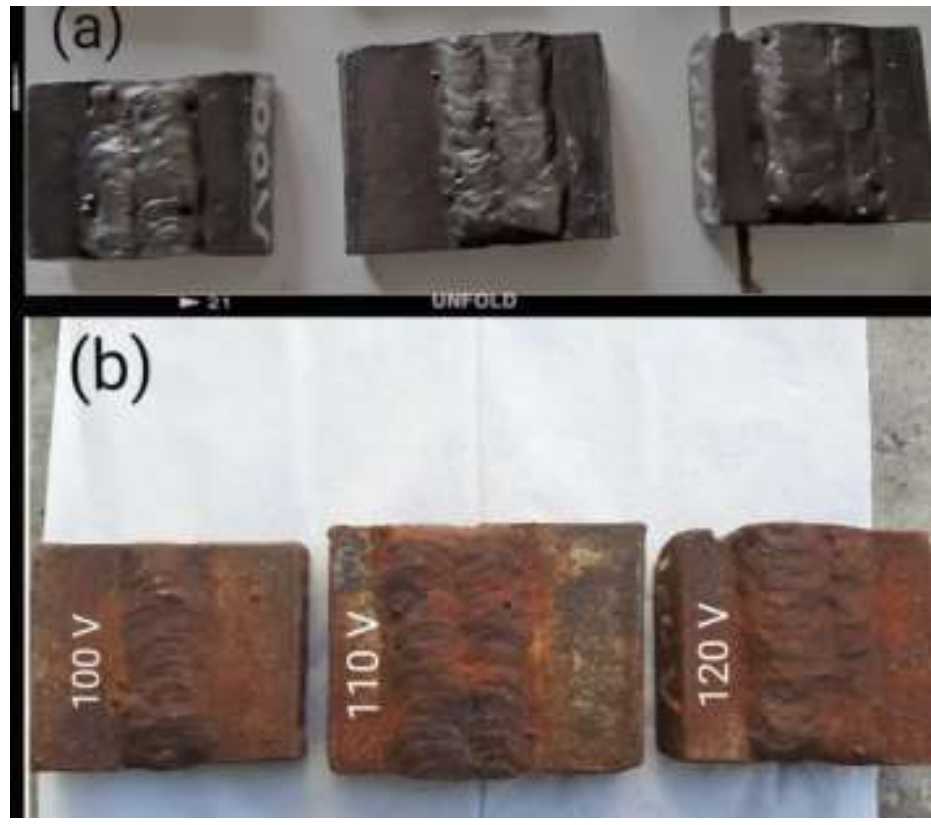

Figure 5. Photo of the Specimen, (a) before testing, (b) after testing

From the Figure 4, it is known that the welding current not only affects the strength of the material, it also affects the corrosion rate of the AISI 1045 material. From the research that been conducted, it is known that the higher the current applied then the corrosion rate also become higher too. When using a welding current of 100 Ampere, the corrosion rate is only around 13.98 mils per year, at a current of 110 Ampere, the corrosion rate increases to 15.67 mils per year, and at a current of $120 \mathrm{~A}$, the corrosion rate reaches 17.25 mils per year. If the value of the corrosion rate above is compared with Table 1, it can be seen that up to 120 Ampere welding current, this material can be categorized into have good corrosion resistance.

From Figure 5, it can be seen that the corrosion experienced by the AISI 1045 plate was evenly distributed, whether it weld with welding currents of 100 Ampere, 110 Ampere, or 120 Ampere. Apart from that, from Figure 5 can also be seen that the largest area that is corroded (the area 
in red - orange colour) in specimens happened in the welding current of 120 Ampere, this is in line with the data in Figure 4, where the welding current of 120 Ampere has the highest corrosion rate, so that with the same exposure time, the specimens that are given current of 120 Ampere will lose the most weight, as a result the area that was corroded will be even wider.

\section{Conclusion}

Based on the experiment that been carried out, it can be concluded that with increasing the welding current then the yield strength, tensile, and fracture strength of the material will be increasing too. Likewise, the elongation of the material will increase as the welding current increases. Apart from the strength of the material, the welding current also has the effect of increasing the corrosion rate as the welding current increases. From this research it can also be seen that the corrosion that occurs in the specimens is evenly distributed.

\section{References}

[1] A. Pramono, "Karakterisrik Mekanik Proses Hardening Baja Aisi 1045 Media Quenching Untuk Aplikasi Sprochet Rantai," J. Ilm. Tek. Mesin CakraM, vol. 5, no. 1, pp. 32-38, 2011.

[2] "AISI 1045 Carbon Steel - AISI 1045 Medium Carbon Steel," All Metals \& Forge Group. [Online]. Available: https://www.steelforge.com/aisi-1045/. [Accessed: 26-Aug-2020].

[3] J. Robert W. Messler, PRINCIPLES OF WELDING. Singapore: WILEY-VCH Verlag GmbH \& Co. KGaA, 2004.

[4] M. Khafifudin, "The Effect Of Current On SMAW Welding To Tensile Strength And Micro Structure Of Low Carbon Steel," 4th Int. Conf. Eng. Technol. Dev., no. Icetd, pp. 173-177, 2017.

[5] Rohit Jha and A. K. Jha, "Influence of Welding Current and Joint Design on the Tensile Properties of SMAW Welded Mild Steel Joints," Int. J. Eng. Res. Appl., vol. 4, no. 6, pp. 106$111,2014$.

[6] Anon, "G1-90, Standard Practice for Preparing, Cleaning, and Evaluating Corrosion Test Specimens.," ASTM Spec. Tech. Publ., vol. 90, no. Reapproved, pp. 505-510, 1985.

[7] M. G. Fontana, Corrosion engineering, Third edit. McGraw-Hill, 1986.

[8] F. Priyantoro, B. Santosa, and H. Supomo, "Analisa Pengaruh Luasan Scratch Permukaan Terhadap Laju Korosi Pada Pelat Baja A36 dengan Variasi Sistem Pengelasan," J. Tek. ITS, vol. 1, no. 1, 2012.

[9] T. Ojahan and J. Winata, "Perhitungan Laju Korosi pada Material Baja A36 Akibat Proses Pengelasan Smaw ( Shielded Metal Arc Welding )," J. Mech., vol. 4, pp. 38-44, 2013.

[10] Anon, ASME Section IX-2015 Welding, Brazing, and Fusing Qualifications. ASME, 2015. 